Revista Brasil. Bot., V.30, n.4, p.561-568, out.-dez. 2007

\title{
Rock outcrop vegetation in Brazil: a brief overview
}

\author{
FABIO RUBIO SCARANO ${ }^{1}$
}

(received: July 20, 2007; accepted: November 21, 2007)

\begin{abstract}
Rock outcrop vegetation in Brazil: a brief overview). This paper overviews the special issue of the Brazilian Journal of Botany dedicated to "Rock outcrop vegetation in Brazil". The main topics covered by this issue are phytogeography and vegetation ecology, plant life on shallow soils, plant reproduction and auto-ecology, morpho-physiology and plant adaptation, and finally conservation and global change. This collection of studies, in addition to other recent publications on Brazilian rocky outcrop vegetation, show that measurements of most of the relevant ecological and evolutionary parameters are under way and that scientific attention is now given to most Brazilian regions. However, there are still several gaps to be bridged: 1) inselbergs and high mountains in the Amazon and the Brazilian northeast, in particular, are still largely unknown to science; 2) long-term studies are almost totally unavailable, which hinders global change monitoring and assessment; 3 ) national and international networking are urgently needed to speed up scientific production about such habitats.
\end{abstract}

Key words - high altitude vegetation, mountain biodiversity, rock outcrop vegetation, tropical inselbergs

RESUMO - (Vegetação sobre afloramentos rochosos no Brasil: um breve panorama). Este artigo proporciona um panorama deste suplemento especial da Revista Brasileira de Botânica, dedicado às vegetações brasileiras sobre afloramentos rochosos. Os principais tópicos tratados aqui são fitogeografia e ecologia da vegetação, a vida vegetal sobre solos rasos, reprodução e auto-ecologia de plantas, morfo-fisiologia e adaptação de plantas e, finalmente, conservação e mudanças globais. Esta coleção de estudos, em adição a outras publicações recentes sobre os afloramentos rochosos brasileiros, demonstra que medições dos parâmetros ecológicos e evolutivos mais relevantes estão em andamento e que atenção científica tem sido dada à maioria das regiões brasileiras. No entanto, existem ainda algumas lacunas por preencher: 1) "inselbergs" e/ou grandes elevações na Amazônia e no nordeste brasileiro, em particular, permanecem em grande parte desconhecidos para a ciência; 2) estudos de longa duração são quase que totalmente inexistentes, que impede monitoramento e avaliação das mudanças globais; 3) construção e participação em redes de trabalho nacional e internacional são urgentemente necessários para acelerar a produção científica sobre esses hábitats.

Palavras-chave - biodiversidade de montanhas, "inselbergs" tropicais, vegetação em altitudes elevadas, vegetação sobre afloramentos rochosos

\section{Introduction}

The past few years have seen a growing number of books, special issues of major scientific journals and review papers entirely or partly dedicated to Brazilian biomes. Amazon (Bush et al. 2007) and Atlantic forests (Morellato \& Haddad 2000), "cerrado" (i.e., savanna-like vegetation of Central Brazil; Oliveira \& Marquis 2002), "pantanal" (i.e., wetlands of centre-west Brazil; Silva et al. 2001, Pott \& Pott 2005), "caatinga" (vegetation of the semi-arid zone of the Brazilian northeast; Silva et al. 2004, Araújo et al. 2005), and "campos sulinos" (i.e., grasslands of southern Brazil; Overbeck et al. 2007) have all been subjected to comprehensive syntheses and recent review efforts. Biogeography, vegetation and plant ecology are often the focus of such studies. Thus, it is perhaps not surprising that fields of knowledge such as "Ecology

1. Universidade Federal do Rio de Janeiro, CCS, IB, Departamento de Ecologia, Caixa Postal 68020, 21941-970 Rio de Janeiro, RJ, Brazil. fscarano@biologia.ufrj.br and Environment" and "Plant and Animal Sciences" now emerge as two of the most productive from a scientific point of view in the country (Scarano 2007). Moreover, many such studies subsidize conservation policies and/or initiatives (e.g., Barbosa et al. 2004).

As knowledge on the main Brazilian biomes deepens, there is a parallel trend to increase focus on ecotones, marginal ecosystems and "enclaves", i.e., sub-units inserted or associated to the major biogeographic units of the country. Smith et al. (2001) highlighted the relevance of such peripheral habitat types to biodiversity conservation, while casting doubt on the relevance of the ongoing conservation practice of pinpointing worldwide "biodiversity hotspots" (see Myers et al.2000). Thus, savanna "enclaves" in the Amazon forest (Sanaiotti et al. 2002), "restingas" (i.e., vegetation mosaic on sandy coastal plains) and swamps at the periphery of the Atlantic forest (Scarano 2002), and the interface of "campos" and Araucaria forest in south-Brazil (Duarte et al. 2006) provide some of the many examples of Brazil's richness and diversity in terms of habitat types. 
This special issue of the Brazilian Journal of Botany focuses on one specific type of phytogeographic sub-unit that is recurrent in most of the major Brazilian biomes (see in this issue Martinelli 2007), i.e., vegetation that grows on rocky outcrops.

\section{Phytogeography and vegetation ecology}

Phytogeography and vegetation ecology of rock outcrop plant communities are the dominant topics of this special issue. Interestingly, the various contributions cover rock outcrops inserted in distinct biomes. Porembski (2007) provides a broad picture, and by comparing granitic-gneissic tropical inselbergs in Africa and in the Americas, he forwards a comprehensive list of typical plant communities and associations, and predominant types of adaptations and plant traits. Following the ongoing trend of defining biodiversity hotspots, Porembski (2007) identified three hotspots of inselberg plant diversity that are both rich in species and endemics: (a) southeastern Brazil, (b) Madagascar and (c) southwestern Australia. They are all located within biodiversity hotspots of global importance, such as the Atlantic rain forest (see Myers et al. 2000) of southeastern Brazil. This is a strong indication of the often close relationships between rock outcrops and neighbouring vegetation. This author emphasizes, nevertheless, that for several tropical regions, such as Angola and India, our knowledge about the flora and vegetation of inselbergs is still sparse. Martinelli (2007) is also very precise in this respect and presents the most comprehensive list to date of Brazilian mountain habitats that are poorly known to science. Thus, Porembski (2007) and Martinelli (2007) set the stage for the discussion that follows focusing on specific inselbergs or mountain habitats.

The following papers in this issue are ordered from north to south in the South American continent. Gröger \& Huber (2007) covered the very intriguing inselbergs of the Guayana Shield, in north-eastern South America, which is therefore the closest this issue got to the Brazilian Amazon. Indeed, they divide this region into two floristic districts, and the northern inselberg district reveals phytogeographic relations to the Brazilian Shield as well as to the Caribbean region. The southern inselberg district has connections to the tepui flora. The area where the two districts overlap is a centre of endemisms. While providing this regional account, the authors are also very precise in synthesizing inselberg vegetation as a whole as "a mosaic of marginal habitats" where "a large number of taxa find suitable niches in a quite condensed space". Rull \& Nogué (2007) provide additional interpretation about possible migration routes of plants in Guayana highlands during the Quaternary. These interesting papers raise the expectation about what one should expect to find in terms of inselberg vegetation as one enters the Brazilian Amazon. The voluminous list of Amazonian inselbergs, provided by Martinelli (2007), most of which still require floristic inventory, are a clear call for scientists and conservationists.

The paper of Conceição et al. (2007) concerns "Chapada Diamantina", and hereby represents the Brazilian northeastern region. Therefore, in this special issue, it is the only study set in rock outcrops inserted in the "caatinga" biome (for a list of northeastern mountains and inselbergs, see Martinelli 2007). The type of rock here is quartzite-sandstone, such as in the studies of this issue located at "Serra do Cipó", Minas Gerais, within the "cerrado" biome (Coelho et al. 2007, Figueira \& Del Sarto 2007, Medina \& Fernandes 2007, Velten \& Garcia 2007). Despite the insertion of these rock outcrops in the "caatinga" biome, Conceição et al. (2007) show that the general pattern of monocot dominance (particularly of families such as Velloziaceae, Bromeliaceae, Orchidaceae, Asteraceae and Poaceae), common to other Brazilian rock outcrops in the southeast region and/or on granitegneiss, repeats itself also in this part of the northeast region.

The study of Felfili et al. (2007) is one of several in this issue inserted in the "cerrado" biome. However, while the other four studies were located at "Serra do Cipó", state of Minas Gerais (SE-Brazil), this study focused on an altogether distinct type of vegetation: a semideciduous forest on limestone, in the state of Goiás, Central Brazil. Curiously, although surrounded by a "cerrado" matrix, this vegetation showed floristic links with the "caatinga" of Northeast Brazil, with other patches of seasonal forests in Central Brazil and in the pantanal, and with the Chiquitano forests of Bolivia.

The next two studies focusing on phytogeography and vegetation ecology in this issue are both set in rock outcrops at high altitude, within the Atlantic rain forest biome: the so-called "campos de altitude". They are inserted in the mountain range known as "Serra da Mantiqueira". Caiafa \& Silva (2007) studied vegetation structure on a granitic outcrop at "Serra do Brigadeiro", Minas Gerais, at 1,722 $\mathrm{m}$ of elevation. They found a strong oligarchic structure, with six species only detaining $98.3 \%$ of the relative dominance, and the remaining $1.7 \%$ were accounted for by 22 locally rare species. Oligarchic and/ or monodominant communities have been commonly reported for other vegetation types associated to the Atlantic rain forest biome (Scarano 2002). From a methodological point of view, Caiafa \& Silva's (2007) contribution is 
also very original in that they estimated vegetation cover by using a modern adaptation of the photograph charts method, first proposed by Weaver \& Clements (1938).

Ribeiro et al. (2007a) examined floristics and phytogeography of the rock outcrop vegetation of the Itatiaia plateau, Rio de Janeiro State, at 2,400 m a.s.1. Although this is one of the most studied rock outcrop vegetation in the country (Brade 1956, Segadas-Vianna 1965, Segadas-Vianna \& Dau 1965) - alongside "Serra do Cipó", in Minas Gerais State and the "Pão-de-Açúcar", in the city of Rio de Janeiro - this study shows that there are still many gaps to bridge and controversies to be solved. For instance, Safford (1999a, b) has been referring to this "campo de altitude" as "Brazilian páramos", and this paper presents restrictions to this approach. Moreover, in addition to granite-gneiss, quartzite-sandstone and limestone rock outcrops - which are the substrates of the soil and vegetation islands of the papers previously reviewed here - Itatiaia has nepheline-syenite rocks, which are rather rare in Brazil.

This special issue clearly lacked on studies of the so-called "cangas", i.e., the vegetation on ferruginous rocks typical of the state of Minas Gerais and in some parts of the Amazon. Thus, some recent studies on such plant communities are essential reading for information on floristic elements (e.g., Viana \& Lombardi 2007).

\section{Plant life on shallow soils}

Several papers in this special issue were particularly interested on the relationship between soil and vegetation (Benites et al. 2007, Conceição et al. 2007, Gröger \& Huber 2007, Medina \& Fernandes 2007, Velten \& Garcia 2007). This was quite surprising and welcome given the relative scarcity of papers covering this topic from an ecological or botanical viewpoint.

Conceição et al. (2007) compared four locations at the "Chapada Diamantina", three of which were inselbergs, and found out that floristic structure and composition were less related to distance between sites and site isolation than to characteristics of the soil islands harbouring vegetation. Gröger \& Huber (2007) similarly found that gradients of soil depth (along with water availability) were key factors determining the floristic composition of the inselbergs of the Guayanan shield.

Thus, it is perhaps no coincidence that Benites et al. (2007) took a very specific interest on soil properties of rock outcrop vegetation and compared such features for quartzite-sandstone and granite-gneiss rock outcrops. As they describe, although apparently monotonous, rocky outcrops bear a considerable diversity of pedo-environments and associated vegetation mosaics, greatly determined by local topography and micro-environmental aspects. These shallow soils also vary according to the rock they are associated to, although it can be said that they are characteristically nutrient-poor. It is all the more surprising then that even small differences in nutrient concentration and acidity can be sufficient to trigger floristic differences, as those found by Conceição et al. (2007).

\section{Plant reproduction and auto-ecology}

Medina \& Fernandes (2007) and Velten \& Garcia (2007) focused on a particular compartment of the rock outcrops shallow soils, namely the seed banks. Seed bank data for non-agricultural habitats such as rocky outcrops are rather rare (Thompson et al. 1998), which highlights the relevance of these two studies.

Although seed banks at "Serra do Cipó" were often poorer in species and less dense than surrounding habitats ("cerrado", forest and gallery forest) and than other vegetation types elsewhere, they still housed a number of endemic species (Medina \& Fernandes 2007). Similarly, Velten \& Garcia (2007) compared three species of Eremanthus, a locally abundant Asteraceae genus at "Serra do Cipó", and found that only one of them could form seed banks. A pre-requisite for seed bank formation is prolonged seed dormancy that, therefore, may not be common to many species of the "campos rupestres". Nevertheless, Garcia et al. (2006) have studied seed germination of two shrubs (including one Asteraceae of the genus Baccharis) from the ferruginous canga vegetation and found potential for seed bank formation.

The seeds found in the shallow soils of rock outcrops are the outcome of the process of sexual reproduction. Although in this special issue there is no contribution related to other steps of the reproduction process, such as pollination or dispersal, there are some interesting recent studies covering these topics that were set in Brazilian inselbergs or altitude rock outcrops. For instance, Freitas \& Sazima (2006) studied the pollination system of 124 species from Bocaina Mountain Range, which is ca. 60 $\mathrm{km}$ from the Itatiaia plateau. The Asteraceae family had $32 \%$ (40) of the total species number and the genus Baccharis was responsible for almost $30 \%$ (11) of this group and responded for $100 \%$ of the dioecious species. Another important case study on reproductive biology at rock outcrops is set at "Corcovado" and "Pão-deAçúcar" inselbergs in Rio. Wendt et al. (2001, 2002) studied reproductive isolation vs. hybridization between sympatric and mostly rare Pitcairnia (Bromeliaceae) species on these rock outcrops. Selfing facilitates reproductive isolation 
among Pitcairnia albiflos Herb., P. corcovadensis Wawra, and P. flammea Lind. at "Corcovado" mountain, whereas reproductive barriers between $P$. albiflos and $P$. staminea Lodd. are weak and hybridization seems to be associated to disturbed areas at the "Pão-de-Açúcar".

In this special issue, however, the two studies on reproductive biology examined asexual reproduction, clonal growth and vegetative propagation (Coelho et al. 2007, Figueira \& Del Sarto 2007). Since clonal growth research is still in its infancy in Brazil (see Cirne \& Scarano 2001, Sampaio et al. 2005), these were also highly original contributions to this volume. The genus Leiothrix (Eriocaulaceae) was the object of the two studies on vegetative propagation on rock outcrops published in this issue. Coelho et al. (2007) compared and described the vegetative propagation strategies of four species, which can resort to rhizome propagation, pseudoviviparity or both. Figueira \& Del Sarto (2007) studied Leiothrix flagellaris (Guill.) Ruhl. (Eriocaulaceae), a pseudoviviparous species, i.e., vegetative propagules differentiate in some or all normal sexual flowers in the inflorescence. This unusual reproductive strategy, the authors argue, promote both a fast increase in photosynthetic area and improve recruitment, thus reducing dispersal and establishment failures.

The understanding of reproductive systems and strategies of plant populations clearly benefits from a molecular background. However, patterns of genetic variability and gene flow of tropical inselberg species have only rarely been investigated. Barbará et al. (2007) is a recent example of a study along these lines in Brazil. They found that gene flow in inselberg species of Alcantarea (Bromeliaceae) is markedly lower than comparable bromeliads in more continuous sites. Similar results were found by Franceschinelli et al. (2006) for one out of two Vellozia species studied at "Serra do Cipó". If this pattern is common to other inselberg and rock outcrop plant species in Brazil, the design of conservation strategies for such species should be less than straightforward.

\section{Morpho-physiology and plant adaptation}

The often limiting conditions to plant life that result from low temperatures, drought, soil scarcity, or all those combined, turn rock outcrop plants a common subject target of ecophysiologists and morpho-anatomists. The classic book edited by Rundel et al. (1994) is a typical example. In Brazil, "Serra do Cipó" (e.g., Lüttge et al. 2007a), the Itatiaia plateau (e.g., Camerik \& Werger 1981, Scarano et al. 2001), and "Pão-de-Açúcar" and Urca inselbergs (e.g., Mattos et al. 1997, Duarte et al. 2005,
Scarano et al. 2005) have often hosted such types of study. In this special issue, however, there are only two, but very important, contributions to this topic.

Ribeiro et al. (2007b) examined the leaf anatomy of desiccation-tolerant species of Anemia, a pteridophyte genus common to "Pedra do Itacoatiara", Rio de Janeiro. These plants possess a number of peculiar anatomical features and, perhaps more intriguingly, a combination of mesomorphic leaf blades with xeromorphic petioles. Inselbergs are centres of diversity of desiccation-tolerant plants (Porembski \& Barthlott 2000) and in Brazil this ecophysiological feature is still understudied.

Silva \& Dillenburg (2007) studied water relations in three woody, evergreen species in a granitic outcrop in Rio Grande do Sul, the southern-most state of Brazil, comparing wet and dry season. This ecophysiological description provides curious insights about a possible spatial and temporal partitioning of water resource in vegetation islands as being related to the coexistence of the studied species.

\section{Conservation and global change}

Although clearly all papers in this issue provide elements that might assist decision-makers in designing conservation policies, surely Martinelli's (2007) contribution is the most explicit in this respect. Studies discussing the fragile nature of the flora of inselberg and high altitude vegetation in Brazil, and claiming for their conservation, have often targeted particular habitat types or locations (Meirelles et al. 1999, Scarano 2002, Jacobi et al. 2007). Martinelli's (2007) paper is the first to provide a national perspective of locations, scientific background available and their conservation status. Furthermore, it points out to the need of specific conservation policies for rocky outcrop vegetation at governmental level, irrespective of the larger biomes such vegetation types are inserted into. Similar international initiatives are discussed as positive examples that Brazil, perhaps, should follow.

Another relevant feature of this special issue is that no paper dealt with directly with global change-related topics, except for Benites et al. (2007) who mention that marshy peats found at "Serra da Mantiqueira" have a high potential for carbon sequestration. They cited Simas et al. (2005) who found that carbon stocks of highland peats in this region can reach $1,500 \mathrm{Mg} \mathrm{ha}^{-1}$, which is approximately five times more than mountain slopes with primary Atlantic forest. Moreover, I found no other reference to global change-related studies being carried out in Brazilian mountains and inselbergs. This is in marked contrast with other equivalent habitats in the 
tropical (Halloy 2002, McDonald et al. 2002) and temperate world (Fagre \& Peterson 2002, Gottfried et al. 2002). There is however enough evidence to assume that global warming should reduce available land to plants adapted to mountain habitats, especially those in high altitudes (Spehn et al. 2002).

Such habitats can therefore even be used as monitoring sites for the effect of such climatic changes. Grabherr $e t$ al. (2001) offered a very relevant recommendation in this respect, which I propose to be applicable to Brazilian rock outcrop vegetation as a whole. They argue, along the same lines as Martinelli (2007), that efforts for developing a global network of long term ecological monitoring sites in such plant communities should be started immediately. Moreover, they suggest indicators for short-term effects (<10 years; e.g., flowering phenology of vascular plants, composition and abundance of moss species); medium term effects (between 10 and 50 years; e.g., plant community structure, composition and individual horizontal distribution, occurrence of exotics and pathogens, and functional classifications based on ecophysiological requirements); and long term effects (> 50 years; e.g., landscape patterning close to treeline). The reader of this special issue will certainly note that many of such types of measurements are discussed here and that some others are already being undertaken in Brazil (e.g., mosses: Costa 1995, Lüttge et al. 2007b), however often under a more limited spatial and temporal scale.

\section{Final remarks}

This special issue shows that Brazil is producing relevant research in rock outcrop vegetation in low and high altitudes. Surprisingly, most research topics are covered and most Brazilian geopolitical regions have groups dedicated to investigating such habitats. However, the gaps to be filled are still very many. For instance, (1) inselbergs and high mountains in the Amazon and the Brazilian northeast, in particular, are still largely unknown to science; (2) long-term studies are almost totally unavailable, which hinders global change monitoring and assessment; (3) national and international networking are urgently needed to speed up scientific production about such habitats. These scientific goals will be more easily attained if supported by specific governmental incentive policies. Perhaps this special issue will be the necessary milestone of a new era on inselberg and mountain biological research in Brazil.

Acknowledgements - I thank Fábio de Barros for his partnership in preparing this special issue: his critical reading, dedicated editorial work, and patience were the keystones of this project; Alexandre F. da Silva (in memoriam) who idealized and stimulated the "Rock Outcrop Symposium" in the "Congresso Nacional de Botânica" (National Botanical Congress) at Viçosa, 2004; CNPq (Brazilian Council for Scientific Research) for a productivity grant; and Faperj (Rio de Janeiro Foundation for Scientific Research) for a "Cientista do Nosso Estado" grant.

\section{References}

ARAÚJO, F.S., RODAL, M.J.N. \& BARBOSA, M.R.V. (eds.) 2005. Análise das variações da biodiversidade do bioma caatinga. Ministério do Meio Ambiente, Brasília.

BARBARÁ, T., MARTINELLI, G., FAY, M.F., MAYO, S.J. \& LEXER, C. 2007. Population differentiation and species cohesion in two closely related plants adapted to neotropical high-altitude "inselbergs" Alcantarea imperialis and Alcantarea geniculata (Bromeliaceae). Molecular Ecology 16:1981-1992.

BARBOSA, F.A.R., SCARANO, F.R., SABARÁ, M.G. \& ESTEVES, F.A. 2004. Brazilian LTER: Ecosystem and biodiversity information in support of decision-making. Environmental Monitoring and Assessment 90:121133.

BENITES, V.M., SIMAS, F.N.B., SCHAEFER, C.E.G.R., SANTOS, H.G. \& MENDONÇA, B.A.F. 2007. Soils associated to rock outcrops in the highlands of Serras da Mantiqueira and Espinhaço, southeastern Brazil. Revista Brasileira de Botânica 30:569-577.

BRADE, A.C. 1956. A flora do Parque Nacional do Itatiaia. Boletim do Parque Nacional do Itatiaia 5:1-114.

BUSH, M.B., CRISCI, J. \& WHITTAKER, R.J. 2007. Special issue Conservation and Biogeography of Amazonia. Journal of Biogeography 34:1289-1289.

CAIAFA, A.N. \& SILVA, A.F. 2007. Structural analysis of the vegetation on a highland granitic rock outcrop in southeast Brazil. Revista Brasileira de Botânica 30:657664.

CAMERIK, A.M. \& WERGER, M.J.A. 1981. Leaf characteristics of the flora of the High Plateau of Itatiaia, Brazil. Biotropica 13:39-48.

CIRNE, P. \& SCARANO, F.R. 2001. Resprouting and growth dynamics after fire of the clonal shrub Andira legalis (Leguminosae) in a sandy coastal plain in southeastern Brazil. Journal of Ecology 89:351-357.

COELHO, F.F., CAPELO, C.D.L., NEVES, A.C.O. \& FIGUEIRA, J.E.C. 2007. Vegetative propagation strategies of four rupestrian species of Leiothrix (Eriocaulaceae). Revista Brasileira de Botânica 30:687-694.

CONCEIÇÃO, A.A., PIRANI, J.R. \& MEIRELLES, S.T. 2007. Floristics, structure and soil of insular vegetation in four quartzite-sandstone outcrops of Chapada Diamantina, Northeast Brazil. Revista Brasileira de Botânica 30:641-655. 
COSTA, D.P. 1995. Musgos do Pico da Caledônea, Município de Nova Friburgo, Rio de Janeiro, Brasil. Acta Botanica Brasilica 8:141-191.

DUARTE, H.M., GEßLER, A., SCARANO, F.R., FRANCO, A.C., MATTOS, E.A., NAHM, M., RENNENBERG, H., RODRIGUES, P.J.F.P., ZALUAR, H.L.T. \& LÜTTGE, U. 2005. Ecophysiology of six selected shrub species in different plant communities at the periphery of the Atlantic Forest of SE - Brazil. Flora 200:456-476.

DUARTE, L.S., SANTOS, M.M.G., HARTZ, S.M. \& PILLAR, V.D. 2006. Role of nurse plants on Araucaria forest expansion over grassland in South Brazil. Austral Ecology 31:520-528.

FAGRE, D.B. \& PETERSON, D.L. 2002. Modelling and monitoring ecosystem responses to climate change in three North American mountain ranges. In Mountain biodiversity: a global assessment (C. Körner \& E.M. Spehn, eds.). Parthenon, London, p.249-259.

FELFILI, J.M., NASCIMENTO, A.R.T., FAGG, C.W. \& MEIRELLES, E.M. 2007. Floristic composition and community structure of a seasonally deciduous forest on limestone outcrops in Central Brazil. Revista Brasileira de Botânica 30:611-621.

FIGUEIRA, J.E.C. \& DEL SARTO, M.C.L. 2007. Clonal growth and dispersal potential of Leiothrix flagellaris (Eriocaulaceae) in the rocky grasslands of southeastern Brazil. Revista Brasileira de Botânica 30:679-686.

FRANCESCHINELLI, E.V., JACOBI, C.M., DRUMMOND, M.G. \& RESENDE, M.F.S. 2006. The genetic diversity of two Brazilian Vellozia (Velloziaceae) species with different patterns of spatial distribution and pollination biology. Annals of Botany 97:585-592.

FREITAS, L. \& SAZIMA, M. 2006. Pollination biology in a tropical high altitude grassland in Brazil: interactions at the community level. Annals of the Missouri Botanical Gardens 93:465-516.

GARCIA, L.C., BARROS, F.V. \& LEMOS FILHO, J.P. 2006. Comportamento germinativo de duas espécies de canga ferrífera: Baccharis retusa DC. (Asteraceae) e Tibouchina multiflora Cogn. (Melastomataceae). Acta Botanica Brasilica 20:445-450.

GOTTFRIED, M., PAULI, H., REITER, K. \& GRABHERR, G. 2002. Potential effects of cllimate change on alpine and nival plants in the Alps. In Mountain biodiversity: a global assessment (C. Körner \& E.M. Spehn, eds.). Parthenon, London, p.213-223.

GRABHERR, G., GOTTFRIED, M. \& PAULI, H. 2001. High mountain environment as indicator of global change. In Global change and protected areas (G. Visconti, M. Beniston, E.D. Iannorelli \& D. Barba, eds.), Kluwer, Dordrecht, p.331-345.

GRÖGER, A. \& HUBER, O. 2007. Rock outcrop habitats in the Venezuelan Guayana lowlands: main vegetation types and floristic components. Revista Brasileira de Botânica 30:599-609.
HALLOY, S.R.P. 2002. Variations in community structure and growth rates of high-Andean plants with climatic fluctuations. In Mountain biodiversity: a global assessment (C. Körner \& E.M. Spehn, eds.). Parthenon, London, p.225-237.

JACOBI, C.M., CARMO, F.F., VINCENT, R.C. \& STEHMANN, J.R. 2007. Plant communities on ironstone outcrops: a diverse and endangered Brazilian ecosystem. Biodiversity and Conservation 16:21852200.

LÜTTGE, U., DUARTE, H.M., SCARANO, F.R., MATTOS, E.A., CAVALIN, P.O., FRANCO, A.C. \& FERNANDES, G.W. 2007a. Physiological ecology of photosynthesis of five sympatric species of Velloziaceae in the rupestrian fields of Serra do Cipó, Minas Gerais, Brazil. Flora 202:637-646.

LÜTTGE, U., MEIRELLES, S.T. \& MATTOS, E.A. 2007 b. Strong quenching of chlorophyll fluorescence in the desiccated state in three poikilohydric and homoiochlorophyllous moss species indicates photooxidative protection on highly light exposed rocks of a tropical inselberg. Journal of Plant Physiology [in press; available online at http://www.sciencedirect.com/ science/journal/01761617].

MARTINELLI, G. 2007. Mountain biodiversity in Brazil. Revista Brasileira de Botânica 30:587-597.

MATTOS, E.A., GRAMS, T.E.E., BALL, E., FRANCO, A.C., HAAG-KERWER, A., HERZOG, B., SCARANO, F.R. \& LÜTTGE, U. 1997. Diurnal patterns of chlorophyll a fluorescence and stomatal conductance in several species of two types of coastal vegetation in southeastern Brazil. Trees Structure and Function 11:363-369.

MCDONALD, D.J., MIDGLEY, G.F. \& POWRIE, L. 2002. Scenarios of plant diversity in South African mountain ranges in relation to climate change. In Mountain biodiversity: a global assessment (C. Körner \& E.M. Spehn, eds.). Parthenon, London, p.261-266.

MEDINA, B.M.O. \& FERNANDES, G.W. 2007. The potential of natural regeneration of rocky outcrop vegetation on rupestrian field soils in Serra do Cipó, Brazil. Revista Brasileira de Botânica 30:665-678.

MEIRELLES, S.R., PIVELLO, V.R. \& JOLY, C.A. 1999. The vegetation of granite rock outcrops in Rio de Janeiro, Brazil, and the need for its protection. Environmental Conservation 26:10-20.

MORELLATO, L.P.C. \& HADDAD, C.F.B. 2000. Introduction: The Brazilian Atlantic Forest. Biotropica 32:786-792.

MYERS, N., MITTERMEIER, R.A., MITTERMEIER, C.G., FONSECA, G.A.B. \& KENT, J. 2000. Biodiversity hotspots for conservation priorities. Nature 403:853858.

OLIVEIRA, P.S. \& MARQUIS, R.J. 2002. The Cerrados of Brazil. Columbia University Press, New York. 
OVERBECK, G.E., MÜLLER, S.C., FIDELIS, A., PFADENHAUER, J., PILLAR, V.D., BLANCO, C.C., BOLDRINI, I.I., BOTH, R. \& FORNECK, E.D. Brazil's neglected Biome: the South Brazilian Campos. Perspectives in Plant Ecology, Evolution and Systematics [in press; available online at http://www.sciencedirect.com/ science/journal/14338319].

POREMBSKI, S. 2007. Tropical inselbergs: habitat types, adaptive strategies and diversity patterns. Revista Brasileira de Botânica 30:579-586.

POREMBSKI, S. \& BARTHLOTT, W. 2000. Granitic and gneissic outcrops (inselbergs) as centers of diversity for desiccation-tolerant vascular plants. Plant Ecology 151:19-28.

POTT, A. \& POTT, V. 2005. Features and conservation of the Brazilian Pantanal wetland. Wetlands Ecology and Management 12:547-552.

RIBEIRO, K.T., MEDINA, B.M.O. \& SCARANO, F.R. 2007a. Species composition and biogeographic relations of the rock outcrop flora on the high plateau of Itatiaia, SE-Brazil. Revista Brasileira de Botânica 30:623-639.

RIBEIRO, M.L.R.C., SANTOS, M.G. \& MORAES, M.G. 2007b. Leaf anatomy of two Anemia Sw. species (Schizaeaceae-Pteridophyta) occurring on a rock outcrop in Niterói, RJ, Brazil. Revista Brasileira de Botânica 30:695-702.

RULL, V. \& NOGUÉ, S. 2007. Potential migration routes and barriers for vascular plants of the neotropical Guyana highlands during the Quaternary. Journal of Biogeography 34:1327-1341.

RUNDEL, P.W., SMITH, A.P. \& MEINZER, F.C. (eds.) 1994. Tropical alpine environments: plant form and function. Cambridge University Press, Cambridge.

SAFFORD, H. 1999a. Brazilian Páramos I. An introduction to the physical environment and vegetation of the campos de altitude. Journal of Biogeography 26:693712.

SAFFORD, H. 1999b. Brazilian Páramos II. Macro- and mesoclimate of the campos de altitude and affinities with high mountain climates of the tropical Andes and Costa Rica. Journal of Biogeography 26:713-737.

SAMPAIO, M.C., PICÓ, F.X. \& SCARANO, F.R. 2005. Ramet demography of a nurse bromeliad in Brazilian restingas. American Journal of Botany 92:674-681.

SANAIOTTI, T.M., MARTINELLI, M.A., VICTORIA, R.L., TRUMBORE, S.E. \& CAMARGO, P.B. 2002. Past vegetation changes in Amazon savannas determined using carbon isotopes of soil organic matter. Biotropica 34:2-16.

SCARANO, F.R. 2002. Structure, function and floristic relationships of plant communities in stressful habitats marginal to the Brazilian Atlantic rain forest. Annals of Botany 90:517-524.

SCARANO, F.R. 2007. Perspectives on biodiversity science in Brazil. Scientia Agricola 64:439-447.
SCARANO, F.R., DUARTE, H.M., RIBEIRO, K.T., RODRIGUES, P.J.F.P., BARCELLOS, E.M.B., FRANCO, A.C., BRULFERT, J., DELÉENS, E. \& LÜTTGE, U. 2001. Four sites with contrasting environmental stress in southeastern Brazil: relations of species, life form diversity, and geographical distribution to ecophysiological parameters. Botanical Journal of the Linnean Society 136:345-364.

SCARANO, F.R., DUARTE, H.M., FRANCO, A.C., GESSLER, A., MATTOS, E.A., NAHM, M., RENNENBERG, H., ZALUAR, H.L.T. \& LÜTTGE, U. 2005. Ecophysiology of selected tree species in different plant communities at the periphery of the Atlantic forest of SE Brazil I. Performance of three different species of Clusia in an array of plant communities. Trees Structure and Function 19:497-509.

SEGADAS-VIANNA, F. 1965. Ecology of the Itatiaia range, southeastern Brazil. I - altitudinal zonation of the vegetation. Arquivos do Museu Nacional 53:7-30.

SEGADAS-VIANNA, F. \& DAU, L. 1965. Ecology of the Itatiaia range, southeastern Brazil. II - Climates and altitudinal climatic zonation. Arquivos do Museu Nacional 53:31-53.

SILVA, C.J., WANTZEN, K.M., NUNES-DA-CUNHA, C. \& MACHADO, F.A. 2001. Biodiversity in the Pantanal wetland, Brazil. In Wetlands: assessment, function, conservation. (B. Gopal, W.J. Junk \& J.A. Davis, eds.), Backhuys, Netherlands, p.187-215.

SILVA, L.G.R. \& DILLENBURG, L.R. 2007. Water relations of tree species growing on a rock outcrop in the Itapuã State Park, RS. Revista Brasileira de Botânica 30:703711.

SILVA, J.M.C., TABARELLI, M., FONSECA, M.T. \& LINS, L.V. (eds.) 2004. Biodiversidade da caatinga: áreas e ações prioritárias para conservação. Ministério do Meio Ambiente, Universidade Federal de Pernambuco, Brasília.

SIMAS, F.N.B., SCHAEFER, C.E.G.R., FERNANDES FILHO, E.I., CHAGAS, A.C., \& BRANDÃO, P.C. 2005. Chemistry, mineralogy and micropedology of highland soils on crystalline rocks of the Serra da Mantiqueira, southeastern Brazil. Geoderma 125:187201.

SMITH, T.B., KARK, S., SCHNEIDER, C.J., WAYNE, R.K. \& MORITZ, C. 2001. Biodiversity hotspots and beyond: the need for preserving environmental transitions. Trends in Ecology and Evolution 16:431.

SPEHN, E.M., MESSERLI, B. \& KÖRNER, C. 2002. A global assessment of mountain biodiversity: synthesis. In Mountain biodiversity: a global assessment (C. Körner \& E.M. Spehn, eds.). Parthenon, London, p.325-330.

THOMPSON, K., BAKKER, J.P., BEKKER, R.M. \& HODGSON, J.G. 1998. Ecological correlates of seed persistence in soil in the north-west European flora. Journal of Ecology 86:163-169. 
VELTEN, S.B. \& GARCIA, Q.S. 2007. Variation between three Eremanthus species in their ability to form a seed bank. Revista Brasileira de Botânica 30:713-719.

VIANA, P.L. \& LOMBARDI, J.A. 2007. Florística e caracterização dos campos rupestres sobre canga na Serra da Calçada, Minas Gerais, Brasil. Rodriguésia 58:159-177.

WEAVER, J.E. \& CLEMENTS, F.E. 1938. Plant Ecology. McGraw-Hill, New York.
WENDT, T., CANELA, M.B.F., FARIA, A.P.G. \& RIOS, R.I. 2001. Reproductive biology and natural hybridization between two endemic species of Pitcairnia (Bromeliaceae). American Journal of Botany 88:1760-1767.

WENDT, T., CANELA, M.B.F., KLEIN, D.E. \& RIOS, R.I. 2002. Selfing facilitates reproductive isolation among three sympatric species of Pitcairnia (Bromeliaceae). Plant Systematics and Evolution 232:201-212. 